\title{
Racial Differences in Perceived Disorder in Three Gentrifying Neighborhoods
}

\author{
Daniel Monroe Sullivan ${ }^{1}$, James D. Bachmeier ${ }^{2}$ \\ ${ }^{1}$ Department of Sociology, Portland State University, Portland, USA \\ ${ }^{2}$ Population Research Institute, Pennsylvania State University, University Park, USA \\ Email: dsulliva@pdx.edu
}

Received May $18^{\text {th }}$, 2012; revised June 20 $0^{\text {th }}$ 2012; accepted June 30 ${ }^{\text {th }}, 2012$

\begin{abstract}
To what extent do diverse residents living in the same neighborhood perceive problems? Do they have similar levels of concern regarding drug dealing, graffiti, or litter in the streets? This study uses survey data, probability sampling, and regression analysis to complement qualitative studies that examine perceived disorder in racially diverse, gentrifying neighborhoods. Findings from 571 residents in three neighborhoods in Portland, Oregon reveal that there are substantial racial differences: white residents perceive more disorder - both crimes and incivilities - than do blacks. And, in contrast to what contact theory would suggest, the racial differences are more pronounced among longer tenured residents than newcomers. Social class_-at least the dimension measured by ownership status-is also important, with homeowners perceiving more than renters. These findings suggest that neighborhoods, and indeed entire cities, that have racially and socioeconomically diverse residents need to find ways to create stronger social bonds and solve what Sampson (2009) calls the "paradox of diversity meets disorder".
\end{abstract}

Keywords: Race; Social Class; Neighborhoods; Gentrification; Perceived Disorder

\section{Introduction}

I suspect that much of the gentrification debate is actually a coded reference to the contestation of blacks and whites for urban space...As is so often the case, the action in gentrification probably stems from an interaction between race and class in the urban environment. Because of this interaction, it is difficult to comprehend the effect of one without taking into account the other (Massey, 2002: p. 175).

Scholars from across a range of disciplines and countries recognize that perceived disorder-a social constructivist perspective that people to varying degrees understand visible signs of crime and incivilities as problematic (Sampson \& Raudenbush, 2004) — can have a big impact on cities (Body-Gendrot, 2000; Bottoms, 2009; Sampson, 2009; Davis, forthcoming) and neighborhoods, including neighbor relations and the functioning of local organizations (Skogan, 1990; Perkins \& Taylor, 1996; Sampson \& Raudenbush, 2004). Similar perceptions of order and disorder among residents can facilitate neighborhood dynamics (Kefalas, 2003; Low, 2003), but differing perceptions can strain them.

This strain is exacerbated in gentrifying neighborhoods due to such polarizing conditions as displacement and social class differences between poorer and less educated longtime residents and wealthier and more educated newcomers. When gentrifying neighborhoods are also going through racial change - especially from majority black to majority white-the resulting racial distance, mistrust, and tension makes the situation worse (Anderson, 1990; Sullivan \& Shaw, 2011). Researchers agree that even though some newcomers are attracted to gentrifying neighborhoods in part because of its "edginess" and diversity (Perez, 2002; Lloyd, 2006; Sampson, 2009) they tend to perceive more disorder, resulting in significant neighborhood change. Newcomers who perceive more crime, for example, tend advocate for more police enforcement (Smith, 1996; Deener, 2010) and against affordable housing (Fraser, 2004; Sullivan \& Picarsic, 2012); newcomers who perceive more incivilities may, for example, participate in neighborhood organizations that advocate for residential and commercial "beautification" projects and complain to the city about properties that do not meet their standard of orderliness (Maly, 2005).

Despite agreeing that newcomers tend to perceive more disorder in gentrifying neighborhoods, qualitative methodologies of previous studies have not been able to examine thoroughly the salience of race for understanding differences in perceived disorder. That is because newcomers differ from longtime residents in a number of important ways: they are more likely to be white, own their home, and have more money and education. Our study of residents in three neighborhoods in Portland, Oregon complements qualitative studies by using survey data and regression analysis to examine which characteristics are most salient for understanding differences in perceived disorder. The racial composition of our sample further enhances our analysis: the neighborhoods of study have had a substantial amount of both black and white residents since the 1950s. This racial diversity allows us to examine if there are differences in perceived disorder between longtime white and black residents.

Second, qualitative studies tend to focus on highly visible actors and organizations. Although providing rich description, it is uncertain how representative they are of neighborhood residents, most of whom do not publicly express their opinion about disorder. Less activist residents who perceive high levels of disorder, however, can influence their neighborhood in important ways. They may spend less time in public spaces (Anderson, 1990, 1999; Meares \& Kahan, 1998), socialize only with like-minded neighbors (Hartigan, 1999), not send their 
children to the local public school or play in their neighborhood streets (Prince, 2002), avoid local stores (Anderson, 1990; Maly, 2005), and complain to the police and city agencies (Pattillo, 2007; Deener, 2010). Our study complements these qualitative studies by randomly selecting 571 residents to measure the perceptions of a more representative sample. We measure perceived disorder using nine indicators to measure its criminal and incivilities dimensions and examine its relationship to race, as well as social class, ownership status, and length of residence.

\section{Perceived Disorder in Gentrifying Neighborhoods}

Although it is well documented that newcomers in gentrifying neighborhoods tend to perceive more disorder, it is unclear how salient race and other resident characteristics are for understanding these differences. Hartigan's (1999) qualitative analysis of the racially and socioeconomically mixed Corktown neighborhood in Detroit illustrates this point. He documents in rich detail how middle-class white newcomers perceive more disorder than do long-time black residents, some of whom are renters. These newcomers tend to socialize in private spaces with other newcomers, limit their time spent in neighborhood public spaces, and participate in a neighborhood organization that advocates closing a local homeless shelter. It is unclear the extent to which their heightened level of perceived disorder is influenced by the fact that they are white (who tend to perceive blacks as disorderly), homeowners (who have a large and relatively fixed investment, are concerned about their property value, and are drawn to others who share their interests in historic preservation), college educated (who have been socialized to view certain neighborhood conditions as disorderly), or newcomers (who are not yet used to their new neighbors and are instead comparing them to their previous middle-class ones).

\section{The Race Hypothesis}

The literature on residential segregation and racial attitudes documents that racial stereotyping continues to have a pervasive effect on assessments of neighborhood desirability and on decisions to move in or out (Ellen, 2000). Each group has contrasting views of which racial mix constitutes the most desirable neighborhood (Farley et al., 1994; Schuman et al., 1997; Farley, 2011). Blacks, who have learned from historical experience that majority-white neighborhoods are hostile and that majority-black neighborhoods are stigmatized and suffer from disinvestment, tend to prefer a 50-50 mix. Whites, who have been socialized in a culture that associates blacks with disorder and are fearful of rising crime (Anderson, 1990) and declining property values (Farley et al., 1994), tend to be comfortable in majority-white neighborhoods (Timberlake, 2000; Farley, 2011). This tendency also extends to white gentrifiers, who are hesitant to move into predominantly black neighborhoods (Straight, 2010). In both cases the least desirable neighborhoods are disliked because the particular racial mix conjures images of disorder. We expect to find, therefore, that in neighborhoods like ours that have a racial mix that is more in line with the preference of blacks, black residents perceive less disorder than whites.

In addition, Pattillo (1999) and Woldoff (2011) argue that black residents, both those living in poor and middle-class neighborhoods, tend to be exposed to more disorder than whites, ranging from crimes like drug dealing, gangs, and violence to incivilities like trash and loud noise. Straight (2010) reaches a similar conclusion in her analysis of 85 gentrifying neighborhoods: black gentrifiers tend to move into predominantly black neighborhoods, and ones whose current residents are less stable and more vulnerable; white gentrifiers, in contrast, tend to move into white neighborhoods, and ones whose current residents are more stable and less vulnerable than those encountered by black gentrifiers.

These findings are explained in large part due to racial segregation and the way in which it concentrates poverty (and disorder), and the way in which middle-class black neighborhoods are often near poor black ones. The current level of neighborhood disorder in a racially integrated gentrifying neighborhood, therefore, would more than likely have to surpass past levels of disorder for it to be perceived by blacks as problematic. White residents, in contrast, are less likely to have been exposed to high levels of disorder previously and, thus, are more likely to perceive current levels of disorder as problematic.

\section{The Social Class Hypothesis}

Most previous gentrification studies have had a difficult time disentangling race and social class because of the strong correlation between them (e.g., Kasinitz, 1988; Anderson, 1990; Smith, 1996; Fraser, 2004; Martin, 2008; Deener, 2010; Lloyd, 2011). A few studies, however, have looked at neighborhoods undergoing social class changes with no major racial changes and found that residents with higher socioeconomic status tend to perceive more disorder. Different dimensions of social class -ownership status, education, and income-may offer some insight in explaining the reasons for this finding.

Ownership status. It is reasonable to hypothesize that homeowners perceive more disorder than do renters since houses are oftentimes a person's largest financial investment (Low, 2003) and they are a relatively fixed investment. If homeowners want to sell their house, for example because they perceive too much disorder, it would be cumbersome. They oftentimes invest time and money to make their house "market ready," and then they have to put it on the market, find a buyer, and then buy a house themselves in another neighborhood. Renters, in contrast, can simply leave their dwelling (and the neighborhood) when their contract expires.

This owner-renter difference helps explain why homeowners are more likely to exercise what Olson (1965) refers to as "voice"-i.e., influencing their neighborhood's dynamicsrather than "exit". It also helps explain why homeowners are more likely to be more sensitive to the reputation of their neighborhood, since the value of their home is heavily influenced by it (Kasinitz et al., 1998). House values can soar in neighborhoods that the real estate industry and potential buyers consider "up and coming," but values can plummet in neighborhoods considered run-down or crime-ridden (Galster, Tatian \& Smith, 1999; Mele, 2000).

Education. Although positively correlated with homeownership, education may provide additional explanations for differences in perceived disorder within gentrifying neighborhoods. First, since college-educated residents are likely to have been raised by college-educated parents and socialized by other college-educated adults, they are more likely to have developed 
tastes for "orderly" behavior (Low, 2003). The most extreme version of this tendency is residents of gated communities, who are attracted to a neighborhood where crime is low (due in part to a private security force and limited public access) and "disorderly” behaviors such as littering and not maintaining yards are against the rules (Blakely \& Snyder, 1997).

Income. Due to residential class segregation, those who are poor or who were raised in a poor household are more likely to have spent time living in poor neighborhoods, which tend to experience higher levels of crime and incivilities (Anderson, 1990, 1999). It seems reasonable to assume, therefore, that those who have been living near or amongst disorder for a substantial period of time would be less aware of or bothered by disorder in their current neighborhood. In addition, those who are poor tend to have less access to private spaces and therefore do more activities in the public eye (Duneier, 1999; Pattillo, 2007). It is reasonable to expect that they would be less bothered by others engaging in public behavior and, therefore, perceive less disorder than wealthier residents.

Evidence from previous qualitative studies in gentrifying neighborhoods supports the social class hypothesis: in gentrifying neighborhoods with little racial diversity newcomers tend to perceive more disorder. In case studies of "black gentrification”-i.e., middle-class blacks moving into historically poor, black neighborhoods-black gentrifiers perceive more disorder. This is despite the fact that some middle-class black gentrifiers feel a "deep sense of racial responsibility" (Pattillo, 2007) and a desire for "racial uplift" (Boyd, 2000). They try to reduce crime by complaining to the police and joining neighborhood organizations that advocate for more police enforcement (Prince, 2002; Pattillo, 2007). Gentrifiers tend to associate crime with incivilities and, therefore, make a concerted effort to limit them. They try to reduce (or at least not increase) poor people in the neighborhood by limiting homeless shelters, public housing, and low-income housing (Hartigan, 1999; Fraser, 2004; Pattillo, 2007; Sullivan \& Picarsic, 2012), and pressuring landlords to create more restrictive screening criteria for potential renters (Pattillo, 2007). They may also be bothered by poor people's presence in public spaces, whether it is repairing cars in the street, barbequing in the park, or "loitering" outside apartment buildings or bars (Levy \& Cybriwsky, 1980; Prince, 2002; Pattillo, 2007).

In addition, they may attempt to change their neighborhood's "disorderly" reputation through encouraging positive media coverage (Kasinitz, 1988), changing the name of the neighborhood (Mele, 2000; Sullivan \& Shaw, 2011), and even redrawing neighborhood boundaries to exclude poor, minority residents who live in public housing (Kasinitz, 1988). Other actions include promoting "beautification” projects (Prince, 2002), including forcing local businesses to conform to a middle-class storefront aesthetic (Kasinitz et al., 1998; Levy \& Cybriwsky, 1980; Maly, 2005), courting middle-class potential homebuyers via neighborhood tours (Kasinitz, 1988), and getting the city to designate the neighborhood as historic (Kasinitz, 1988; Maly, 2005).

Historic preservation designation is particularly effective in increasing property values (Tournier, 1980) and enforcing a particular kind of middle- or upper-middle-class sense of aesthetics. Brown-Saracino (2004) argues that historic preservation attracts gentrifiers who embrace historic and architectural qualities and who prioritize historic preservation over "social preservation”-i.e., long-time residents and businesses/organizations, and their cultural practices.

\section{Years Living in the Neighborhood}

Socio-economic differences in perceived disorder could be exacerbated by how long residents have lived in the neighborhood because old-timers and newcomers may use different reference points to evaluate the current state of the neighborhood. Residents who have lived in the neighborhood since before gentrification started, when it suffered from serious crime and disinvestment and had a substantial amount of vacant lots and buildings, may perceive less disorder now. More recent arrivals, in contrast, may have higher expectations since they are comparing current conditions to those in the neighborhood from which they moved (or in which they were raised). Simply put, they may not have lived in their current neighborhood long enough to notice the changes.

Some scholars also argue that there is a "wave effect" among gentrifiers (Pattison, 1983; Butler, 2003). First-wave or "riskoblivious” gentrifiers are more likely to have a lower socioeconomic status than later-arriving or "risk-averse" ones. Lloyd (2002) argues that some in-movers during the first stage are attracted to the "bohemian chic," which is an attraction to diversity, urban grit, and the illicit (see also Perez, 2002; Ley, 2003), because it solidifies their claim to edginess and distinguishes them from later-arriving, "inauthentic” Yuppies.

Kerstein (1990) found that later-arriving gentrifiers, in contrast, are wealthier and are more likely to have moved from the suburbs, approve of upscale development, and be attracted to their house for its architectural and historical value and its potential as a financial investment. And, most important, laterarriving gentrifiers are more critical of neighborhood services like garbage collection. These findings suggest that later-arriving gentrifiers have a higher set of what Low (2003) calls "norms of middle-class civility" and, therefore, are more likely to be sensitive to neighborhood disorder.

Contact theory supports this hypothesis, arguing that social interaction with out-groups improves individuals' views of out-group members as they reassess preconceived notions of the group (Olds, 2012). Although there is still some disagreement about what conditions need to exist for contact theory to work, many studies have found a positive association between increased racial contact and positive attitudes toward the out-group (Siegleman \& Welch, 1993; Pettigrew \& Troop, 2000). In a similar manner, Anderson (1990) found that the more time gentrifiers spent living in the neighborhood the more "streetwise" they were. They became more sophisticated and nuanced, for example, in assessing whether a situation in the neighborhood's public spaces was truly worthy of concern.

\section{Hypotheses}

On the basis of the above literature review, we will test the following hypotheses:

1) Whites perceive more neighborhood disorder than do blacks.

2) Homeowners perceive more neighborhood disorder than do renters.

3) Those with a higher socioeconomic status perceive more neighborhood disorder.

4) The less time a resident has lived in the neighborhood, the more disorder they perceive. 


\section{History of Three Gentrifying Neighborhoods}

This paper examines three neighborhoods in Portland, Oregon, which share important similarities. They were predominantly poor and black since the 1950s, suffering from decades of disinvestment and housing discrimination (Gibson, 2007). During the 1980s and early 1990s they experienced high crime, fueled in part by gang activity and a crack cocaine epidemic. But during the 1990s these neighborhoods began to gentrify. They have experienced a decrease in vacant lots, rising housing prices, and an increase in public and private investment. In addition, many of the newer residents are white, with middle-class incomes and college degrees (Burk, 2006). Currently, all three neighborhoods are diverse in four ways that are related to gentrification: race, ownership status, social class, and length of residence in the neighborhood.

\section{The Eliot Neighborhood}

Although these three neighborhoods possess some similar characteristics, they differ in other respects. The Eliot neighborhood began to gentrify first, starting in the early-to mid-1990s. This neighborhood is populated by historic churches and turn-of-the-century Victorian houses, many of which have been recently renovated. Eliot, however, also has a large amount of institutionalized housing (e.g., drug and alcohol rehabilitation facilities). The city has recently renovated Eliot's main commercial thoroughfare with new sidewalks, bus stops, median strip with trees, and drinking fountains. This avenue contains several dozen stores, ranging from a Nike outlet store, coffeehouses and restaurants, to car repair shops and social service agencies. Although it is not as thoroughly marketed as artistic or creative as the Alberta neighborhood, some of its gentrifiers are part of the "creative class" and express a desire to live amongst diversity (Florida, 2002).

\section{The Alberta Neighborhood}

Gentrification started later in the Alberta neighborhood, from the mid- to late-nineties, but the rate of change has been faster. Many businesses on the main commercial strip, as well as some residents, are making a concerted effort to turn it into the "Alberta Arts” district (Sullivan \& Shaw, 2011). Artists, art galleries, a monthly art walk, and public art, along with enterprising real estate agents, have cultivated a new identity, one that has a bohemian, "alternative" edge to it. The main commercial street has a food co-op, a vegan restaurant, a number of independent coffee houses, yoga studios, and a core group of local business owners and residents who are vehemently against chain stores (Lopas, 2003).

\section{The Concordia Neighborhood}

The Concordia neighborhood is a less clear example of gentrification. However, it has experienced several changes that indicate that it is gentrifying. Many of the houses and their landscapes have been renovated. More white, middle-class residents have moved in, and services have emerged to serve them, including an upscale organic grocery store, pharmacy, coffee shops, and restaurants.

The Concordia neighborhood has several features that would suggest that its residents would perceive less disorder than those living in Eliot and Alberta. Its housing stock has always had the largest share of homeowners, the lowest poverty rate, the lowest percentage black (whites tend to associate blacks with disorder), and the lowest crime rate.

\section{Data and Methods}

Data come from a face-to-face survey of 571 residents in three neighborhoods in Portland, Oregon. The sampling frame consists of housing units that were randomly selected. We surveyed English-speaking adults, but excluded those in institutionally sponsored housing such as drug and alcohol rehabilitation houses since their stay is often temporary and not of their own choosing. To have a representative sample, surveyors returned many times (and at different times of the day, and on different days of the week) in an attempt to secure a survey. We also sent postcards that described the survey to selected households a few days before going to their door. Given that the majority of residents self-identify as black or white, non-Hispanic, we exclude those in other racial and ethnic categories.

The dependent variable is perceived neighborhood disorder, which consists of five items related to criminal disorder (drug dealing, assaults and muggings, burglaries and thefts, vandalism and graffiti, and organized gangs) and four items related to incivilities (loud music, other loud noises, trash in the streets, and not maintaining lawns or property). Each of the nine items had three response categories (serious problem, minor problem, or no problem), resulting in an additive index score ranging from 0 to 18 (Cronbach's alpha $=0.794$ ).

Race is the main independent variable and is measured using a binary that is scored 1 for white, non-Hispanic and 0 for black. Three other independent variables relate directly to gentrification. Socioeconomic status is measured two ways: ownership status is a binary that is scored 1 for homeowner and 0 for renter and education is a binary that is scored 1 for college degree and 0 for less than college degree. Due to the face-toface nature of the surveying, we felt that income-another important dimension of social class-was too personal to ask, especially given the wide income range of residents (including some with very low incomes). Length of time living in the neighborhood is measured in years. Bi-variate analysis indicates that those who have lived in the neighborhood for about five to ten years perceive more disorder than newcomers and old-timers. Therefore, we also include the square of years living in the neighborhood to model this curvilinear relationship.

We also include a number of control variables. Age is measured in years. Some previous research has found that the elderly have a greater fear of crime, which is related to perceived disorder (Skogan \& Maxfield, 1981; Baba \& Austin, 1989). Sex is a binary scored 1 for male and 0 for female. Some findings indicate that women have a greater fear of crime, again related to perceived disorder (Skogan \& Maxfield, 1981; Perkins \& Taylor, 1996; Austin, Furr, \& Spine, 2002). Child at home is a binary scored 1 for one or more children living at home and 0 for none. One study found parents with children have a greater fear of crime (Ross \& Mirowsky, 2001). The two neighborhood-level variables are binary: Eliot and Alberta; Concordia is the contrast category.

To examine the relationship between race and perceived disorder, as well as ownership status, education, years living in the neighborhood, and control variables, we use ordinary least squares regression. The regression has four models: Model 1 just examines the effect of race; Model 2 includes two dimensions of social class: ownership status and education; Model 3 
adds years living in the neighborhood; and Model 4 contains the control variables and is the full model.

\section{Results}

\section{Descriptive Statistics}

Table 1 illustrates the descriptive statistics, including for the whole sample and stratified by race. As is typical of gentrifying neighborhoods that are going through racial change, whites are more likely to have a college degree (63.2\% v. $18.3 \%)$ and own their home $(66.1 \%$ v. $48.9 \%)$. Black residents have on average lived in the neighborhood longer (12.8 years v. 8.1) and are older (45.1 years old v. 40.5).

The overall sample perceives both dimensions of disorder — crimes and incivilities_as being similarly problematic in their neighborhoods. About half the respondents, for example, cite the crimes of burglaries/thefts and drug dealing as problematic; they are less than half as likely to report organized gangs and assaults and muggings as such. Similarly, about half cite the incivilities of trash in the streets and loud noises (other than music) as problematic.

\section{The Salience of Race}

Table 1 also presents the level and type of perceived disor- der stratified by race.

Supporting our hypothesis at the bi-variate level, whites overall have a higher perceived disorder index score than blacks (4.5 v. 3.3). This trend holds true for both perceptions of criminal disorder and incivilities. Whites, in fact, perceive more disorder regarding eight of the nine individual disorder items (only "organized gangs" is not statistically significant).

Given that race is associated with three other important aspects of residents living in gentrifying neighborhoods that are undergoing racial change-whites are more likely to be college-educated, newcomers, and homeowners-we use regression analysis to see if race has an independent and nonspurious effect on perceived disorder. Results from Table 2 further support the race hypothesis, showing that across all four regression models blacks are significantly less likely than whites to perceive disorder, even after controlling for two dimensions of social class and years living in the neighborhood.

\section{The Social Class Hypothesis: Ownership, Not Education}

In addition to race, there is some support for the social class hypothesis. When examining the two social class variables simultaneously, Model 4 of Table 2 illustrates that ownership status is more salient than education in predicting perceived

Table 1.

Descriptive statistics of variables, stratified by race.

\begin{tabular}{|c|c|c|c|}
\hline & Overall Mean & Blacks & Whites \\
\hline \multicolumn{4}{|l|}{ Dependent Variables } \\
\hline Perceived Disorder Index ${ }^{\mathrm{a}}$ & $4.23^{\mathrm{b}}$ & 3.32 & 4.50 \\
\hline \multicolumn{4}{|l|}{ Dimension 1: Perceptions of Crime ${ }^{c}$} \\
\hline Burglaries/thefts & $50.7 \%^{\mathrm{b}}$ & $35.4 \%$ & $55.4 \%$ \\
\hline Drug dealing & $49.9 \%^{\mathrm{b}}$ & $41.7 \%$ & $52.4 \%$ \\
\hline Vandalism/graffiti & $44.4 \%^{\mathrm{b}}$ & $30.8 \%$ & $48.4 \%$ \\
\hline Organized gangs & $25.7 \%$ & $26.2 \%$ & $25.6 \%$ \\
\hline Assaults/muggings & $20.6 \%{ }^{\mathrm{b}}$ & $14.6 \%$ & $22.5 \%$ \\
\hline \multicolumn{4}{|c|}{ Dimension 2: Perceptions of Incivilities ${ }^{c}$} \\
\hline Trash in the streets & $52.3 \%^{\mathrm{b}}$ & $36.9 \%$ & $56.8 \%$ \\
\hline Loud noises (other than music) & $45.5 \%^{\mathrm{b}}$ & $33.6 \%$ & $49.1 \%$ \\
\hline Not maintaining lawns/property & $38.5 \%{ }^{\mathrm{b}}$ & $30.5 \%$ & $40.9 \%$ \\
\hline Loud music & $36.0 \%{ }^{\mathrm{b}}$ & $29.2 \%$ & $38.0 \%$ \\
\hline \multicolumn{4}{|l|}{ Independent Variables } \\
\hline College Degree & $52.8 \%^{\mathrm{b}}$ & $18.3 \%$ & $63.2 \%$ \\
\hline Homeowner & $62.2 \%{ }^{\mathrm{b}}$ & $48.9 \%$ & $66.1 \%$ \\
\hline Years Living in Neighborhood & $8.07^{\mathrm{b}}$ & 12.77 & 6.67 \\
\hline Age & $40.50^{\mathrm{b}}$ & 45.06 & 39.15 \\
\hline Gender (Male) & $45.1 \%$ & $43.8 \%$ & $45.5 \%$ \\
\hline Child Living in Home & $28.0 \%^{\mathrm{b}}$ & $48.1 \%$ & $22.0 \%$ \\
\hline Eliot Neighborhood & $32.6 \%$ & $39.7 \%$ & $30.5 \%$ \\
\hline Alberta Neighborhood & $37.8 \%$ & $35.1 \%$ & $38.6 \%$ \\
\hline Concordia Neighborhood & $29.6 \%$ & $25.2 \%$ & $30.9 \%$ \\
\hline $\mathrm{N}$ & 571 & 131 & 440 \\
\hline
\end{tabular}

${ }^{\mathrm{a}}$ The Perceived Disorder Index ranges from 0 - 18. ${ }^{\mathrm{b}}$ Chi-square test of proportional differences between blacks and whites are significant at the 0.05 level ${ }^{\mathrm{c}}$ Residents perceived them as a minor or serious problem. 
Table 2.

OLS regression estimates of perceived disorder. ${ }^{a}$

\begin{tabular}{|c|c|c|c|c|}
\hline & Model 1 & Model 2 & Model 3 & Model 4 \\
\hline Race (Blacks) & $-1.18^{* * *}$ & $-1.01^{* *}$ & $-.98^{* *}$ & $-.90^{* *}$ \\
\hline College Degree & & .26 & .21 & .15 \\
\hline Homeowner & & .39 & .43 & $.76^{*}$ \\
\hline Years in Neighborhood & & & .04 & .06 \\
\hline Years in Neighborhood (squared) & & & -.01 & $-.01^{*}$ \\
\hline Age & & & & -.01 \\
\hline Gender (Male) & & & & .16 \\
\hline Child Living in Home & & & & -.50 \\
\hline Eliot Neighborhood ${ }^{\mathrm{b}}$ & & & & $1.49^{* * *}$ \\
\hline Alberta Neighborhood ${ }^{\mathrm{b}}$ & & & & $1.48^{* * *}$ \\
\hline Constant & $4.50^{* * *}$ & $4.09^{* * * *}$ & $4.01^{* * *}$ & $2.78^{* * * *}$ \\
\hline Adjusted R2 & .02 & .02 & .03 & .07 \\
\hline
\end{tabular}

${ }^{*} p<.05 ;{ }^{* *} p<.01 ;{ }^{* * *} p<.001$; aerceived disorder is measured by an index $(0-18)$; ${ }^{\mathrm{b}}$ The Concordia neighborhood is the contrast category.

disorder. Even after controlling for race and education, homeowners are still more likely to perceive neighborhood problems than are renters. This supports the argument that homeowners are more sensitive to neighborhood problems, perhaps due to the large and relatively fixed nature of their house investment and their inability to exit easily from the neighborhood. The other indicator of social class-education-is not statistically significant once ownership status and race are taken into account. These findings suggest that the social class indicator most directly tied to residents' financial well-being-homeownership-more strongly correlates to perceived disorder.

\section{Years Living in the Neighborhood Matters but...}

Our "years living in the neighborhood" hypothesis is only partially supported. We hypothesized that longer tenured residents would perceive less disorder since there is now less crime, fewer vacant lots and buildings, and other tangible signs of disorder than in the past. Many of the newer arriving residents, most of whom have more money than longer-time residents, have probably moved in from more "orderly" neighborhoods and, therefore, would perceive more disorder in their current neighborhood 1) because they would not have been around long enough to witness the decline in crime, vacant lots/buildings, etc. and 2) because their point of reference is more likely to be a more "orderly" neighborhood. After conducting a bi-variate analysis with perceived disorder, however, we realized that our respondents who lived in the neighborhood for about five to ten years perceive the most disorder, and newcomers and long-time residents perceived less. (That is why we added a squared version of "years living in the neighborhood" variable to the regression models.)

Perhaps newer residents are not as invested in or knowledgeable about neighborhood conditions as those who have lived in the neighborhood longer. Indeed, further analyses (not reported) find that newcomers are less likely to have family or friends living in the neighborhood, and they are also less likely to be involved in neighborhood organizations, like churches and neighborhood associations.

In Figure 1 we examine whether racial differences in per- ceived disorder fade as residents spend more time living in the neighborhood. That is, as black and white residents reside together over time, do they arrive, as contact theory suggests, to a shared understanding of how they perceive their community, even if such sentiments are not shared when they first become neighbors? None of the results suggest that they do. For each of the five "years living in the neighborhood" categories, whites perceive more disorder. And the racial gap, rather than getting smaller over time, gets larger. The smallest racial gap is for relative newcomers ( 0 - 5 years in the neighborhood), and then it grows larger for the next tenured group (5 - 10 years), and even larger for those living in the neighborhood for more than ten years.

Model 4 of Table 2 indicates that residents in the Eliot and Alberta neighborhoods perceive more disorder. One the one hand, this is not surprising since these two neighborhoods are gentrifying more rapidly and extensively and they have more characteristics associated with perceived disorder-e.g., more poverty, minority residents, crime, and renters - than do Concordia residents. On the other hand, gentrifiers in these two neighborhoods correspond more closely to the "bohemian" or "alternative" residents that Perez (2002), Lloyd (2002, 2006), and Sampson (2009) discuss. Despite their supposed attraction to diversity and "edginess", they perceive more disorder than do those living in the more culturally mainstream Concordia neighborhood. The control variables of age, gender and whether they have a child living at home are not significant.

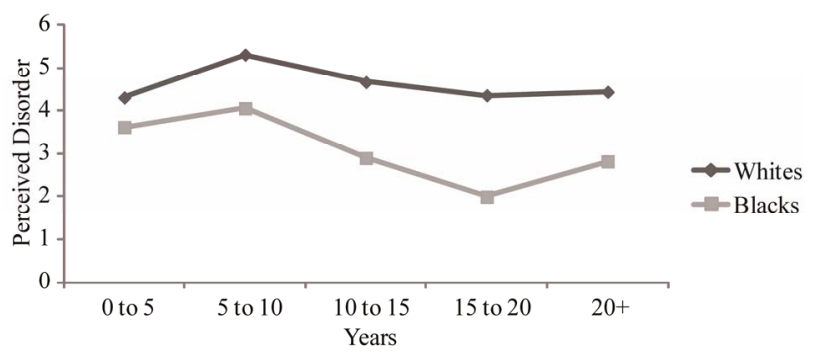

Figure 1.

Perceived disorder, by race and years living in the neighborhood. 


\section{Discussion}

This study contributes to our understanding of race relations in urban neighborhoods by demonstrating the salience of race when examining perceived disorder in gentrifying neighborhoods. We complement qualitative studies by using a random sample of 571 residents, which allows us to understand the perceptions of both activist and non-activist residents. We also employ regression analysis to examine the influence of race while statistically controlling for other important and highly correlated residential characteristics. Finally, we examine neighborhood types that have been largely ignored: socio-economically and racially diverse neighborhoods that have a balance between newcomers and long-time residents and between homeowners and renters.

Our findings support the race hypothesis: whites perceive more disorder than blacks-both crimes and incivilities-after controlling for ownership status, education, and years living in the neighborhood. And these racial differences do not decrease over time, as contact theory would suggest. In fact, we find the opposite: there are greater racial differences among longer tenured residents than newer ones.

Douglas Massey's provocative quote that opened this article regarding the salience of race resonates with our findings. Future research should investigate whether the results from this study are representative of other gentrifying neighborhoods. Portland's black population is smaller than it is in other U.S. cities, and white residents may therefore perceive blacks as less of a racial threat or source of disorder (Brown \& Warner, 1992; Krueger \& Mueller, 2001). Portland, like other western US cities, also has had less racial segregation historically than cities in other parts of the US (Massey \& Denton, 1993). For these reasons, we anticipate greater racial differences in perceived disorder in cities with a larger black population and more racial segregation. Future research should also examine whether our findings hold true in cities in other countries and in regards to other racial and ethnic groups.

The salience of race does not mean that social class is unimportant for understanding tension and social isolation in gentrifying neighborhoods; previous qualitative studies have demonstrated clearly that it does. What our findings suggest, however, is that among the different dimensions of social class, ownership status is more influential than education. In particular, homeowners perceive more disorder than do renters. We speculate that homeowners are more sensitive to disorder because their house is a major, and relatively fixed, investment. It would be difficult for them to leave the neighborhood if problems became too severe and the move would probably result in a financial loss. The lack of statistical significance of education suggests that the social class indicator most closely associated with financial considerations-ownership status-is more salient than the social class indicator that is associated more with culture. One weakness of the current study that future research can address is the salience of income in understanding differences in perceived disorder.

Overall, research has illustrated how perceived disorder leads to powerful neighborhood consequences: e.g., greater police presence and scrutiny of poor and minority residents, pressure to reduce housing for the poor and marginalized, and social isolation between newcomers and old-timers. Given the importance of race in explaining differences in perceived disorder, future research should explore ways to promote what Weisinger
\& Salipante (2005) call “racially bridging ties": relations between organizations that represent the interests of different racial groups. Future research should also examine how neighborhood associations, which in the U.S. are chartered to represent the interests of all its residents, can serve as places for diverse residents in gentrifying neighborhoods to come together to define and solve problems collectively and promote genuine social integration. And it is essential for researchers and policymakers to more fully understand and resolve what Sampson (2009) calls the "paradox of diversity meets disorder": neighborhoods and cities need to find ways for the creative class, who are supposedly attracted to diversity (Florida, 2002), to create meaningful bonds with already existing residents.

\section{REFERENCES}

Anderson, E. (1990). Streetwise. Chicago, IL: The University of Chicago Press.

Anderson, E. (1999). Code of the street. New York: W. W. Norton and Company.

Austin, M. D., Furr, A. L., \& Spine, M. (2002). The effects of neighborhood conditions on perceptions of safety. Journal of Criminal Justice, 30, 417-427. doi:10.1016/S0047-2352(02)00148-4

Baba, Y., \& Austin, M. D. (1989). Neighborhood environmental satisfaction, victimization, and social participation as determinants of perceived neighborhood safety. Environment and Behavior, 21, 763780. doi:10.1177/0013916589216006

Blakely, E. J., \& Snyder, M. J. (1997). Fortress America. Washington, DC: Brookings Institution Press.

Body-Gendrot, S. (2000). The social control of cities? Oxford: Blackwell. doi:10.1002/9780470712757

Bottoms, A. (2009). Disorder, order and control signals. British Journal of Sociology, 60, 49-55. doi:10.1111/j.1468-4446.2008.01214.x

Boyd, M. (2000). Defensive development. Urban Affairs Review, 43, 751-776. doi:10.1177/1078087407313581

Brown, C. M., \& Warner, B. D. (1992). Immigrants, urban politics, and policing in 1990. American Sociological Review, 57, 293-305. doi:10.2307/2096236

Brown-Saracino, J. (2004). Social preservationists and the quest for authentic community. City \& Community, 3, 135-156. doi:10.1111/j.1535-6841.2004.00073.x

Burk, B. (2006). A decade of change on Alberta. The Portland Observer, 11 January.

Butler, T. (2003). Living in the bubble. Urban Studies, 40, 2469-2486. doi:10.1080/0042098032000136165

Davis, D. E. (forthcoming). The Giuliani factor. In G. A. Jones (Ed.), Public sphere and public space in Mexico City, London: Palgrave MacMillan.

Deener, A. (2010). The "black section" of the neighborhood. Ethnography, 11, 45-67. doi:10.1177/1466138109346988

Duneier, M. (1999). Sidewalk. New York: Macmillian.

Ellen, I. G. (2000). Sharing America's neighborhoods. Cambridge, MA: Harvard University Press.

Farley, R., Steeh, C., Krysan, M., Jackson, T., \& Reeves, K. (1994). Stereotypes and segregation. American Journal of Sociology, 100, 750-780. doi:10.1086/230580

Farley, R. (2011). The waning of American apartheid? Contexts, 10, 36-43. doi:10.1177/1536504211418452

Florida, R. (2002). Rise of the creative class. New York: Basic Books.

Fraser, J. C. (2004). Beyond gentrification. Urban Geography, 25, 437457. doi:10.2747/0272-3638.25.5.437

Galster, G. C., Tatian, P., \& Smith, R. (1999). The impact of neighbors who use Section 8 certificates on property values. Housing Policy Debate, 10, 879-917.

Gibson, K. (2007). Bleeding albina. Transforming Anthropology, 15, 3-25. doi:10.1525/tran.2007.15.1.03

Hartigan, J. (1999). Racial situations. Princeton, NJ: Princeton University Press. 
Kasinitz, P. (1988). The gentrification of “Boerum hill”. Qualitative Sociology, 11, 163-182. doi:10.1007/BF00988953

Kasinitz, P., Bazzi, M., \& Doane, R. (1998). Jackson heights, New York. Cityscape, 4, 161-177.

Kefalas, M. (2003). Working-class heroes. Berkeley: University of California Press.

Kerstein, R. (1990). Stage models of gentrification. Urban Affairs Quarterly, 25, 620-639. doi:10.1177/004208169002500406

Krueger, B. S., \& Mueller, P. D. (2001). Moderating backlash. State Politics \& Policy Quarterly, 1, 165-179.

doi:10.1177/153244000100100203

Levy, P. R., \& Cybriwsky, R. A. (1980). The hidden dimensions of culture and class. In S. B. Laska, \& D. Spain (Eds.), Back to the city (pp. 138-155). New York: Pergamon.

Ley, D. (2003). Artists, aestheticisation and the field of gentrification. Urban studies, 40, 2527-2544. doi:10.1080/0042098032000136192

Lloyd, R. D. (2002). Neo-bohemia. Journal of Urban Affairs, 24, 517532. doi:10.1111/1467-9906.00141

Lloyd, R. D. (2006). Neo-bohemia. New York: Routledge.

Lloyd, R. D. (2011). East Nashville skyline. Ethnography, 12, 114-145. doi:10.1177/1466138110387219

Lopas, M. (2003). Whispers of big chain unsettle Alberta's independent spirit. The Oregonian, 7 February.

Low, S. (2003). Behind the gates. New York: Routledge.

Maly, M. (2005). Beyond segregation. Philadelphia: Temple University Press.

Martin, L. (2008). Boredom, drugs, and schools. City \& Community, 7, 331-346. doi:10.1111/j.1540-6040.2008.00270.x

Massey, D. S. (2002). Comment on "does gentrification harm the poor?” Brookings-Wharton Papers in Urban Affairs. Washington, DC: Brookings Institution.

Massey, D. S., \& Denton, N. A. (1993). American apartheid. Cambridge, MA: Harvard University Press.

Meares, T. L., \& Kahan, D. M. (1998) Law and (norms of) order in the inner city. Law and Society Review, 32, 805-838. doi: $10.2307 / 827740$

Mele, C. (2000). Selling the lower eastside. Minneapolis, MN: University of Minnesota Press.

Olds, C. (2012). What role can propinquity play in the development of new national allegiances? Advances in Applied Sociology, 2, 7-18. doi:10.4236/aasoci.2012.21002

Olson, M. (1965). The logic of collective action. Cambridge, MA: Harvard University Press.

Pattillo, M. (2007). Black on the block. Chicago, IL: University of Chicago Press.

Pattillo, M. (1999). Black picket fences. Chicago, IL: University of
Chicago Press.

Pattison, T. (1983). The stages of gentrification. In P. Clay, \& R. Hollister (Eds.), Neighborhood policy and planning (pp. 77-92). Lexington, MA: D. C. Heath.

Perez, G. M. (2002). The other "Real World.”. Urban Anthropology, 31, 37-68.

Perkins, D. D., \& Taylor R. B. (1996). Ecological assessment of community disorder. American Journal of Community Psychology, 24, 63-107. doi:10.1007/BF02511883

Pettigrew, T., \& Troop, L. (2000). Does intergroup contact reduce prejudice? In S. Oskamp (Ed.), Reducing prejudice and discrimination (pp. 93-114). New Jersey: Lawrence Earlbaum Associates, Inc.

Prince, S. R. (2002). Changing places. Urban Anthropology, 31, 5-35.

Ross, C. E., \& Mirowsky, J. (2001). Neighborhood disadvantage and health. Journal of Health and Social Behavior, 42, 258-276. doi:10.2307/3090214

Sampson, R. J. (2009). Analytic approaches to disorder. British Journal of Sociology, 60, 83-93. doi:10.1111/j.1468-4446.2008.01219.x

Sampson, R. J., \& Raudenbush, S. W. (2004). Seeing disorder. Social Psychology Quarterly, 67, 319-342. doi:10.1177/019027250406700401

Schuman, H., Steeh, C., Bobo, L., \& Krysan, M. (1997). Racial attitudes in America. Cambridge, MA: Harvard University Press.

Sieglman, L., \& Welch, S. (1993). The contact hypothesis revisited. Social Forces, 71, 781-795.

Skogan, W. G. (1990). Disorder and decline. Berkeley, CA: University of California Press.

Skogan, W. G., \& Maxfield, M. G. (1981). Coping with crime. Newbury Park, CA: Sage Publications.

Smith, N. (1996). The new urban frontier. New York: Routledge.

Straight, A. J. (2010). Location isn't everything. Atlanta, GA: American Sociological Association.

Sullivan, D. M., \& Picarsic, J. (2012). The subtlety of social exclusion. Sociology Mind, 2, 153-157. doi:10.4236/sm.2012.22020

Sullivan, D. M., \& Shaw S. C. (2011). Race and retail gentrification. Urban Affairs Review, 47, 403-422.

Timberlake, J. M. (2000). Still life in black and white. Sociological Inquiry, 70, 420-445. doi:10.1111/j.1475-682X.2000.tb00918.x

Tournier, R. E. (1980). Historic preservation as a force in urban change. In S. B. Laska, \& D. Spain (Eds.), Back to the city. New York: Pergamon Press.

Weisinger, J. Y., \& Salipante, P. F. (2005). A grounded theory for building ethnically bridging social capital in voluntary organizations. Nonprofit and Voluntary Sector Quarterly, 34, 29-55. doi:10.1177/0899764004270069

Woldoff, R. (2011). White flight/black flight. Ithaca: Cornell University Press. 